\title{
Soils of East Antarctic oasis: Interplay of organisms and mineral components at microscale
}

\author{
Sergey Sedov, Elya Zazovskaya, Dmitriy Fedorov-Davydov, Tatiana Alekseeva
}

Sergey Sedov

serg_sedov@yahoo.com

Instituto de Geología, Universidad Nacional Autónoma de México, Ciudad Universitaria, Coyoacán 04510, CDMX, Mexico.

\section{Elya Zazovskaya}

Institute of Geography, Russian Academy of Sciences, Staromonetnyi per 29, Moscow 109017, Russia.

\section{Dmitriy Fedorov-Davydov \\ Tatiana Alekseeva}

Institute of Physicochemical and Biological Problems of Soil Science, Russian Academy of Sciences, ulitsa Institutskaya, 2, Pushchino 142290, Russia.

BOL. SOC. GEOL. MEX. 2019

VOL. 71 NO. 1

P. $43-63$

http://dx.doi.org/10.18268/BSGM2019v7lnla4

\section{ABSTRACT}

The soils of Antarctic oases - coastal as well as inland ice-free areas limited by ice sheet or ice shelves attract attention as a block of one of the most extreme terrestrial ecosystems of the Earth. The knowledge about early stages of pedogenesis, solum formation and stabilization, interaction between organic and mineral components in these soils is still limited. We performed micromorphological investigation of several thin soil profiles developed under mosses and lichens on the sediments deposited by meltwater in a lake depression of Schirmacher Oasis. Mineral components are dominated by sand particles of primary minerals (mostly quartz, K-Na feldspars and micas) derived from gneiss bedrock. Quartz grains exhibit surface structures indicative of cryogenic fragmentation, whereas biotite has signs of chemical alteration: exfoliation along cleavage planes, deformation of laminae, loss of interference colours and pleochroism. Despite severe environmental conditions, incipient weathering occurs that contribute clay minerals and iron oxides to the fine material. The latter forms discontinuous coatings on the coarse grains providing a chitonic $\mathrm{c} / \mathrm{f}$ related distribution pattern Arrangement of the fine components in form of coatings on coarse grains provides their maximal interaction with soil moisture and organic matter and generation of microhabitats for the microorganisms. Common micromorphological features of the studied soils is a complex groundmass which combines well preserved organic tissues of mosses and lichens and mineral particles spread among them. We conclude that the studied soil bodies are synsedimentary: fluvial (and possibly eolian) deposition of mineral materia that occurs simultaneously with the growth of primitive plants. The mineral grains are trapped between plant tissues which form a framework of the soil matrix. This interlacing provides also conservation of organic material within the soil layer. Studied soils demonstrate similarities with the biological crusts of other present and past extreme terrestrial environments.

Keywords: Antarctic oasis, extreme ecosystems, weathering, biological soil crust.

\section{RESUMEN}

Los suelos de los oasis antárcticos, en las áreas libres de hielo tanto en la costa como tierra adentro rodeadas por los glaciares terrestres o plataformas de hielo, atraen la atención como uno de los componentes de los ecosistemas más extremos de la Tierra. El conocimiento sobre las etapas iniciales de edafogénesis, formación y estabilización del solum, interacción entre los componentes orgánicos y minerales en estos suelos es todavía limitado. Hemos realizado un estudio micromorfológico de algunos perfiles de suelos superficiales, desarrollados en los sedimentos recientes no consolidados, bajo musgos y líquenes en el Oasis Schirmacher. El material mineral está dominado por partículas de arena, de minerales primarios (cuarzo, feldespatos $K$-Na y micas). Los granos de cuarzo demuestran estructuras superficiales indicativas de la fragmentación criogénica, mientras que la biotita tiene signos de alteración química: intemperización a lo largo del clivaje, deformación de las laminillas, pérdida de los colores de interferencia y del pleocroísmo. A pesar de las condiciones ambientales severas, el intemperismo incipiente genera minerales arcillosos y óxidos de hierro que se incorporan al material fino. Este último forma recubrimientos discontinuos sobre los granos gruesos generando un modelo de distribución c/f quitónico. La distribución de los componentes finos en forma de recubrimientos sobre los granos gruesos proporciona una interacción máxima con la humedad del suelo y la materia orgánica y con la generación de micro-hábitats para microorganismos. La característica micromorfológica común de los suelos estudiados consiste en una matriz compleja que combina tejidos bien conservados de musgos y liquenes y partículas minerales distribuidas entre ellos. Se concluye que los cuerpos edáficos estudiados son sin-sedimentarios: el depósito del material mineral ocurre simultáneamente con el crecimiento de las plantas primitivas. Los granos minerales están atrapados entre los tejidos vegetales que forman el "armazón" de la matriz del suelo. Está interacción permite también la conservación de la materia orgánica en la cubierta del suelo. Los suelos estudiados demuestran similitudes a las costras biológicas de otros ambientes terrestres extremos del presente y del pasado.

Palabras clave: oasis antártico, ecosistemas extremos, intemperismo, costra biológica del suelo. 


\section{Introduction}

Antarctica is the continent with the most severe conditions for the existence of life on Earth. These extreme conditions are determined not only by low temperatures, but also by moisture deficiency over most of the continent, high UV-radiation, strong winds, etc. Although these factors supress biota and provoke geomorphic instability, specific soil formation and modification of surface substrate by chemical, physical and biological weathering in the pedogenic environment occur in the icefree areas of Antarctica (Campbell and Claridge, 1987).

Soils of Antarctica can be considered as a unique model for studying surface processes under extreme environmental conditions, not limited to Earth, but also on other planets (Wentworth et al., 2005; Targulian et al., 2010). Following the principle of uniformitarism we speculate that these soils could also be proposed as a recent analogue for the reconstruction of pedospheres during the cold periods of the geological past: from Snowball Earth in Neoproterozoic to Pleistocene glaciations/cryochrons.

The beginning of pedological-geochemical research in Antarctica was marked by publications by Jensen (1916), who presented the first data on the chemical composition of primitive soils of the continent. Glazovskaya (1958) performed a breakthrough study of weathering and primary soil formation on granites and dolerites using the samples collected by the first Soviet Antarctic Expeditions. Over the following five decades, most studies on soil genesis were undertaken in the areas of the Antarctic Dry Valleys and Transantarctic Mountains as well as the Antarctic Peninsula and neighboring islands (Blakemore and Swindale, 1958; Claridge, 1965; Tedrow and Ugolini, 1966; Ugolini and Jackson, 1982; Campbell and Claridge, 1987; Bockheim, 1995, 1997; Beyer, 2000; Michel et al., 2006; Simas et al., 2008; among others) and, more rarely, East Antarctica (Simonov, 1971; Blume and Bölter, 1992; Matsuoka, 1995; Beyer et al., 2004). The attempts were made to integrate the soil information on the continental scale (Bockheim and Ugolini, 1990; Balks et al., 2013) as well as to compare Antarctic and Arctic soil mantles (Tedrow, 1991).

In the early 2000s, a team of Russian soil scientists began studying soils near Russian Research Stations within the coastal region of East Antarctica, on some nunataks, in Wohlthat Mountains (Queen Maud Land) and barely accessible parts of West Antarctica (Abakumov, 2010; Gilichinsky et al., 2010; Goryachkin et al., 2012; Mergelov et al., 2012; Abakumov et al., 2013; Lupachev and Abakumov, 2013; Mergelov, 2014; Zazovskaya et al., 2015, 2017). The new data improved the understanding of the weathering and soil formation processes under extreme conditions, that was reflected in the latest international monograph on Antarctic soils (Bockheim, 2015).

In general, previous investigations produced significant amount of results on typology and classification of the Antarctic soils, development of the cryogenic processes, composition of soil microbial pool as well as specific phenomena of Antarctic pedogenesis like surface salt accumulation and effects of birds in the coastal landscapes. Among scientific problems still to be solved, soil organic matter (SOM) formation and development of organoprofiles recently have drawn attention in the context of the study of the carbon cycle on the continent. Recent research has demonstrated unexpectedly considerable accumulation of organic carbon in the primitive soils of Antarctic oasis with relatively large residence times (estimated by radiocarbon dating of SOM) (Zazovskaya et al., 2015). The question arises about the particular form of SOM accumulation as well as the mechanisms of its formation and stabilization. In particular, the role of interaction of the organic and mineral components in the formation of stable organic matter and development of organo-mineral epipedon in the Antarctic soils draws attention.

Pedogenesis under moss and lichen communities results in the formation of most developed soil profiles and major SOM accumulation in situ 


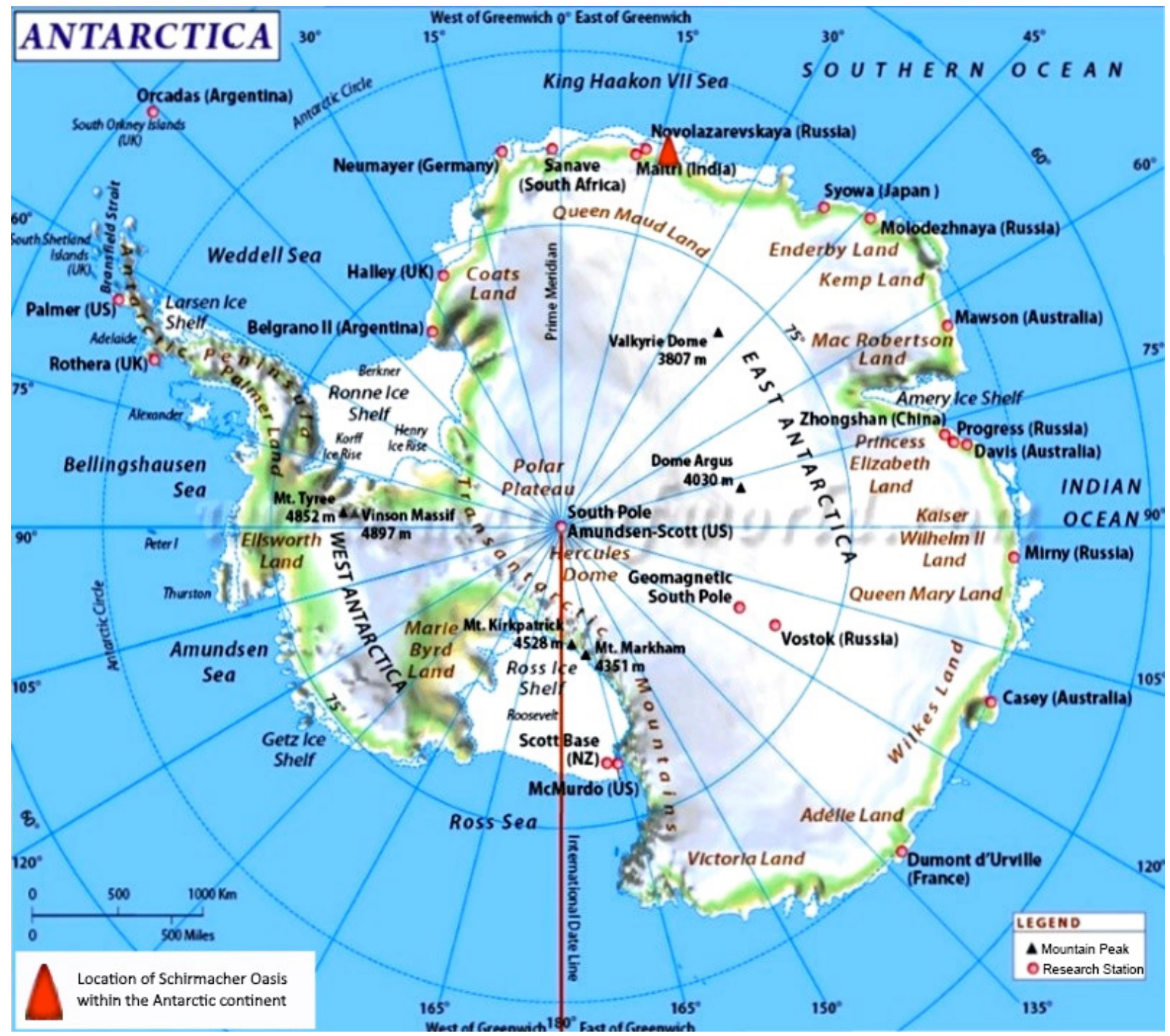

Figure 1 Location of Schirmacher Oasis in the Antarctic continent.

(without inputs of allochtonous organic material e.g. from pinguins and other birds) as in case of ornitogenic soils (Michel et al., 2006) in the Antarctic oasis (Zazovskaya et al., 2015). This puts forward a set of questions about the interplay of living organs of these primitive organisms as well as their post-mortem organic residues with the mineral components of the soil parent materials, resulting in their weathering and development of the organo-mineral surface horizons. Mineral alteration by mosses and lichens was extensively studied in the natural environments and in laboratory experiments (see e.g. the summary by
Chen et al., 2000) however absolute majority of these studies deal with their effects on massive rock surfaces. Our research contributes with the results on primitive soil and alterite development under these communities on the unconsolidated sediments in the deposition sites of the East Antarctic oasis landscape - one of the most extreme environments still hosting these organisms.

To cope with these research topics, micromorphology seems to be the most adequate tool. Micromorphological observations are most efficient for detecting incipient or poorly developed soil processes, for example initial alteration of minerals 
and early stages of plant tissue decomposition. It also provides a unique opportunity to observe the real spatial distribution and architecture of organic and mineral components within the soil epipedon that could help in the understanding SOM accumulation and stabilization in these primitive soils. Earlier micromorphology was successfully applied to study development of the surface crust/endolithic soils on the granitoids under lichens in the East Antarctica (Mergelov et al., 2012). These perspectives motivated us to perform the micromorphological study of the epipedons in the selected profiles of soil developed on the recent deposits under moss and lichen communities in the Schirmacher Oasis in East Antarctica, where earlier chemical analysis and dating of SOM was performed. Based upon the obtained results we infer the formation processes of the studied organo-mineral horizons and compare them with the possible soil analogues in other geographical regions and in the landscapes of geological past.

\section{Study area}

\subsection{GEOGRAPHICAL AND EGOLOGICAL GHARACTERISTICS}

At the present time, ice-free lands in Antarctica with a total area of $45000 \mathrm{~km}^{2}$ constitute $0.35 \%$ of the continent, including $0.03-0.3 \%$ occupied by small Antarctic oases. An Antarctic oasis is a substantial ice-free area that is separated from the ice sheet by a distinct ablation zone and is kept from snow by ablation due to low albedo and a positive radiation balance (e.g. Gore and Pickard, 2007). Oasis can occupy an area from several tens to several thousand square kilometers. The objects of our investigations are located in the Queen Maud Land (QML). QML is that part of Antarctica between longitudes $20^{\circ} \mathrm{W}$ and $45^{\circ} \mathrm{E}$ (Figure 1). QML is the fourth largest ice-free territory of Antarctica, comprised of $3400 \mathrm{~km}^{2}(6.9 \%$ of total ice-free area). The predominant ice-free areas are the Mühlig-Hoffmann and Wohlthat Mountains
(Fimbulheimen), the Sør Rondane Mountains, each one comprised of $900 \mathrm{~km}^{2}$, Queen Fabiola Mountains $\left(200 \mathrm{~km}^{2}\right)$, however the mountains area and nunataks are the least studied in terms of pedology. The most studied areas of QML in terms of soils include the Sør Rondane Mountains and Schirmacher Oasis $\left(35 \mathrm{~km}^{2}\right)($ Zazovskaya et al., 2015).

Schirmacher Oasis is located in the central part of the QML along the Princess Astrid Coast 90 $\mathrm{km}$ south of the Lazarev Sea (Figure 2). The total length of oasis is $18 \mathrm{~km}$ and its width varies from 0.6 to $3.5 \mathrm{~km}$. The territory stretches in a sub-latitudinal direction along the slope of the continental ice shelf. From the north the oasis borders the Lazarev Ice Shelf, which separates it from the sea. The Schirmacher Oasis contains hummocky terrain, with the hills ranging from 10 to $110 \mathrm{~m}$ in relief. The highest point is Mt. Rebristaya at $228 \mathrm{~m}$.

Schirmacher Oasis is one of the coldest Antarctic oases, because of its high latitude, trans-shelf location and the fact it is surrounded by ice. The mean annual air temperature at Novolazarevskaya station is $-10.3^{\circ} \mathrm{C}$; the temperature of the coldest month (August) is $-17.9^{\circ} \mathrm{C}$, and the temperature of the warmest month (January) is $-0.4^{\circ} \mathrm{C}$. In warmer years the monthly mean temperatures of December and/or January can be positive. For example the average positive temperature in January 2017 - $+0.2^{\circ} \mathrm{C}, 2013-+0.5^{\circ} \mathrm{C}, 2011-+1.1^{\circ} \mathrm{C}, 2010$ - $+0.6^{\circ} \mathrm{C}, 2005-+0.5^{\circ} \mathrm{C}, 2004-+0.4^{\circ} \mathrm{C}, 1992-$ $+0.7^{\circ} \mathrm{C}, 1987-+1.4^{\circ} \mathrm{C}$ and in December -2016 - $+0.6^{\circ} \mathrm{C}, 2004-+0.6^{\circ} \mathrm{C}, 2003-+0.2^{\circ} \mathrm{G}$ for the last years of observations. The absolute minimum temperature over the period of observation (1961 to present) was $-44.4^{\circ} \mathrm{C}$, and the maximum was $10.1^{\circ} \mathrm{C}$ (observation in summer 2017). At low temperatures during the summer period, the soil surface is warmed from the intensive solar radiation. On north-facing slopes, rock temperatures of 41.0 to $42.6^{\circ} \mathrm{C}$ were recorded (Bormann and Fritzsche, 1995). We observed soil surface temperatures between $25.5^{\circ}$ and $35.9^{\circ} \mathrm{C}$.

The mean annual wind speed is about $10 \mathrm{~m} \mathrm{~s}^{-1}$. During the summer wind speeds can reach 30 to 


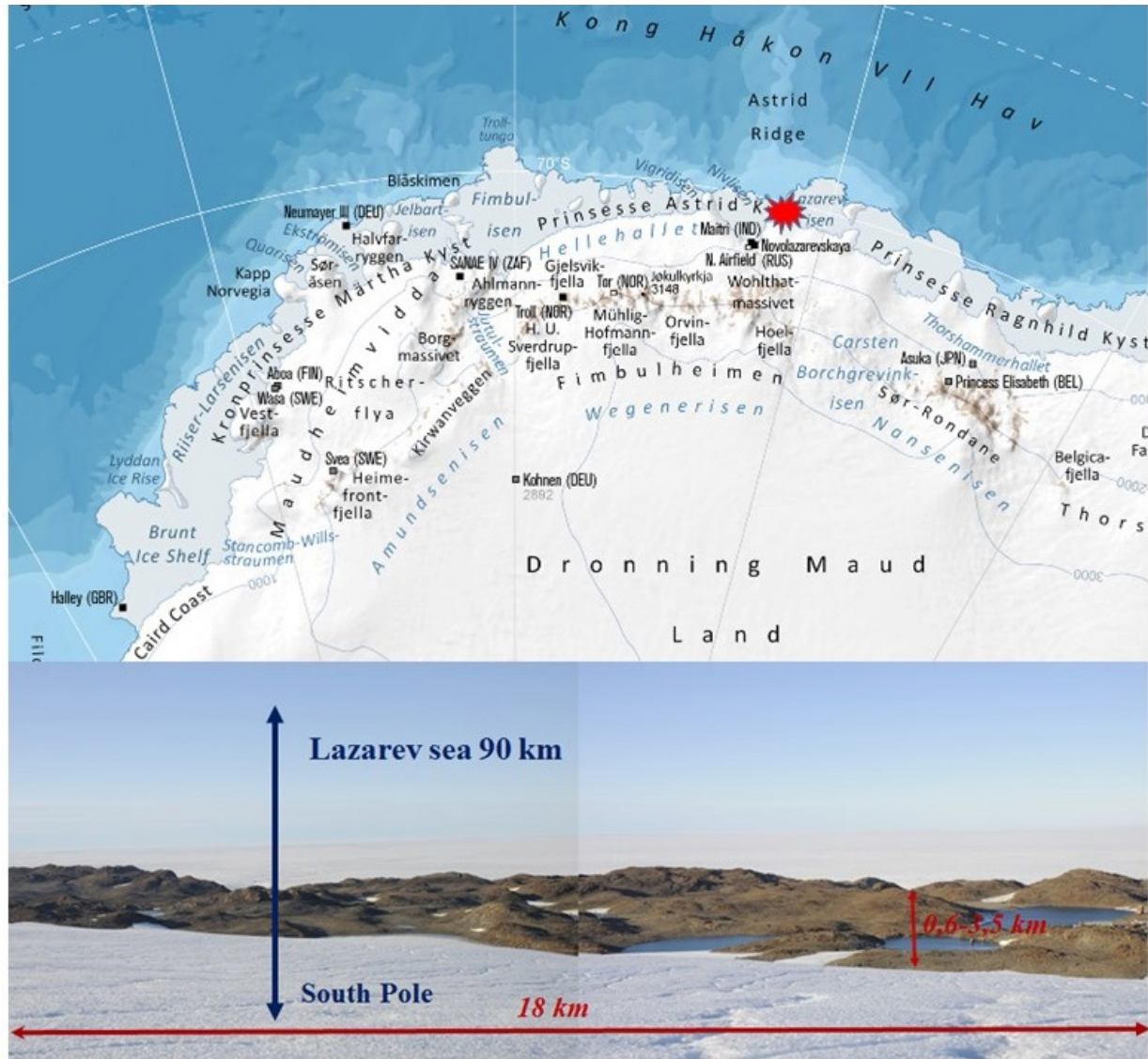

Figure 2 Geographical position of the Schirmacher Oasis.

$35 \mathrm{~m} \mathrm{~s}^{-1}$ and in winter 50 to $55 \mathrm{~m} \mathrm{~s}^{-1}$. The mean annual precipitation is $240 \mathrm{~mm}$, but it is only 10 mm during the summer months of December and January. Evaporation rates vary from 350 to 590 mm $\mathrm{yr}^{-1}$ (Bormann and Fritzsche, 1995; Verkulich et al., 2011). The aridity of the region is due to the positive radiation balance, the low amounts of precipitation and humidity, strong winds, and high evaporation rates.

The terrestrial flora of the Schirmacher Oasis is comprised of 57 species of lichens (Olech and Singh, 2010), 13 species of mosses, and numerous soil algal species (Kurbatova and Ochyra, 2012). The majority of lichens are represented by crustose forms that colonize rock surfaces, more rarely - unconsolidated substrates and sometimes develop over mosses.

The bedrock of the QML is part of the East Antarctic Shield (Bockheim, 2015), characterized by the predominance of Precambrian metamorphic and magmatic rocks. Schirmacher Oasis is comprised of Precambrian metamorphic rocks, including gneisses and crystalline shale. Ultramafic intrusive bodies and numerous pegmatite veins, including rarely aplite, are locally found (Simonov, 1971; Zazovskaya et al., 2015). The low mean annual temperature (about $-10^{\circ} \mathrm{C}$, see above) implies that the study area is underlain by continuous permafrost (Bockheim, 1995). The active layer (seasonally thawed surface horizon) in the Schirmacher Oasis ranges from 30 to $150 \mathrm{~cm}$ in depth. Schirmacher Oasis was glaciated at least three times (Makeev, 1972). The current deglaciation of the Schirmacher Oasis has begun in the Early Holocene and developed in three stages, the second of which resulted in extensive melting 6700-2200 cal $\mathrm{BP}(1 \sigma)$ (Verkulich et al., 2011). The third stage of deglaciation is currently in progress, 
being characterized by further regression of the continental ice sheet, lowering of the lakes water tables and drying of the land. The main agents of the recent sediment transport within the oasis are surface runoff of the snow and ice meltwater (Asthana et al., 2013) which generate sandy surface deposits on the foothills and in depressions. Medium sand is the dominant grain size fraction. The sediment sorting is generally low, however locally increases due to fluvial activity (Srivastava et al., 2012). Contribution of the eolian processes is also probable as far as windblown material was detected within the supraglacial sediments near Schirmacher Oasis (Asthana and Chaturvedi, 1998).

\subsection{LOGAL SOIL-FORMING GONDITIONS}

Within the Schirmacher Oasis, large moss communities with a percentage cover from 45 to $95 \%$ are found, as a rule, near snow patches on mountain slopes or in the upper reaches of valleys. The main limiting factors of pedogenesis under such conditions include: low temperatures and deficiency of liquid water (precipitation occurring only in solid form, with melt waters being the only source of liquid water within the oasis). It is important to highlight how these factors could be modified within the moss colonies. Our long-term (2009-2014) research data have demonstrated that soil profiles under moss communities belong to the group of coldest soils and grounds of the oasis. A soil under a moss-peat cushion (2 $\mathrm{cm}$ thick) has the mean temperature of January $1.4^{\circ} \mathrm{C}$ lower, the annual sum of positive temperatures $111^{\circ} \mathrm{C}$ lower and the sum of temperatures $>5^{\circ} \mathrm{C}$ about $100^{\circ} \mathrm{C}$ lower than the nearby bare ground. Moreover, in the proximity to a snow patch, the winter temperature generally increases and the summer temperature decreases. In addition to these effects of the snow patch on the microclimate, the summer temperature of soil is further lowered due to the presence of the moss cover that hinders soil warming. Despite the summer temperatures of soils under moss cushions are significantly lower than those of moist bare grounds, and the time available for soil development is much shorter in the annual cycle, only in such locations within Schirmacher Oasis soils with accumulation of organic materials have been found (Fedorov-Davydov et al., 2013; Zazovskaya et al., 2015). The extreme character of soil-forming conditions is determined chiefly by an acute moisture deficiency (due to a practically total absence of liquid precipitation and a low humidity) rather than by low temperatures. Therefore, snow patches serve as a principal regulator of bio- and pedodiversity within the oasis. The life of most organisms, primarily, non-vascular plants represented by mosses, is possible only near snow patches that, firstly, accumulate moisture and, subsequently, distribute it. Melt waters from snow patches have influence on the temperature regimes, dynamics of thawing of soils and grounds and also on the development of cryogenic mass exchange processes.

The extreme conditions are also connected with limited periods of the surface exposure and, therefore, limited timescales of the development of physical and biochemical transformation of substrates. Due to the snow cover persistence, the duration of growing season and soil formation can be decreased by days, weeks, frequently by whole seasons and occasionally even by several years. We have observed at the 'Chernoe Lake' site, where further soil investigations were performed, that $50 \%$ of the moss-covered area remained under snow in January (the warmest month) in one of eight seasons of observations (from 2009 to 2017). It should be taken into account that mosses, lichens, green algae and cyanobacteria can photosynthesize and increase their biomass even under snow, provided that the latter is no more than 20-30 cm thick (Zazovskaya et al., 2015). In such cases the snow patch can create a slight greenhouse effect, which facilitates the growth of mosses. Low-rate bio-abiotic interactions may be possible under such conditions. During the years 2012 and 2014 when we observed the snow patch persisting- on the top of the moss-covered soil, the temperatures within the upper $10 \mathrm{~cm}$ of the soil 


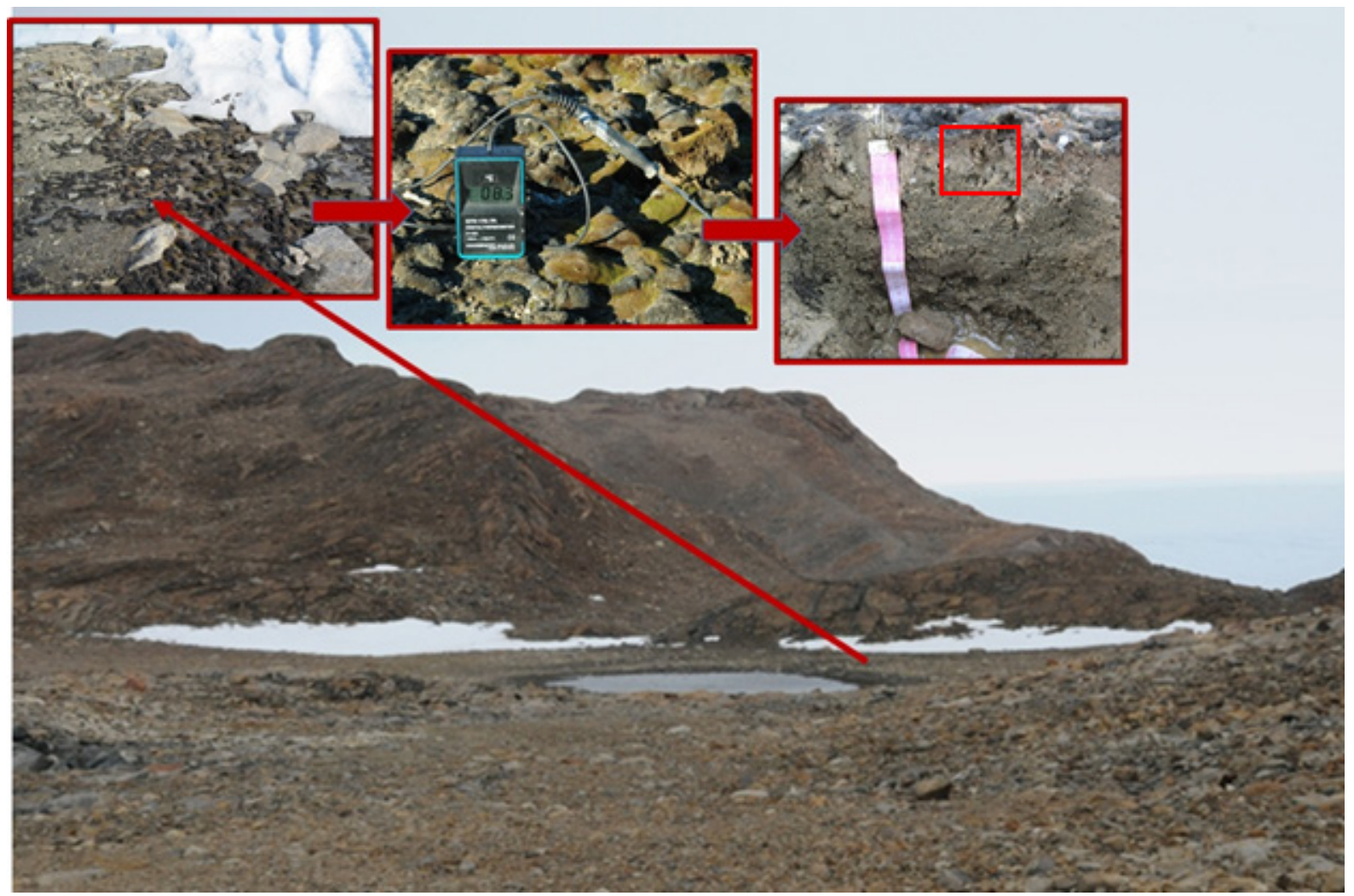

Figure 3 Landscape setting and profile morphology of studied soils; the red frame shows part of the profile from where undisturbed soil block was taken.

remained around zero during the growing season being twice as high as normal in winter. Thus local snow cover dramatically narrowed the amplitude of temperature fluctuations in comparison with that of the year, when snow retreated.

\subsection{FIELD MORPHOLOGICAL STUDY, MICROSCOPIC MATERIALS AND METHODS}

The initial stage of the fieldwork consisted in the selection of the study site and characterization of the local landscape conditions. 5 soil pits: two under crustose lichen biological crusts (profiles 1 and 2) and three under mosses (profiles 3, 4 and 5) were excavated to the depth of the permafrost layer. Soil horizons were described and designated according to Guidelines for soil description (FAO, 2006), the soils were then classified according to international classification World Reference Base for Soil Resources (IUSS Working Group WRB,
2015). Since interactions between the organisms and mineral substrate are mostly manifested in the topsoil we limited the micromorphological study to the upper organo-mineral horizons $\left(\mathrm{O}_{\mathrm{i}}+\mathrm{H}_{\mathrm{i}}+\mathrm{HB}\right)$ from where $6 \times 6 \times 6 \mathrm{~cm}$ undisturbed blocks were collected. Large "mammoth size" thin sections of vertical orientation were prepared after impregnation with the Crystal resin (with the refractive index close to Np of quartz) and studied under an Olympus petrographic microscope. Coarse (sand and silt size) components were identified based upon a set of optical characteristics (color, behavior of Becke line, extinction pattern etc.) according to the guidebooks on microscopic mineral identification (Pichler and Schmitt-Riegraf, 1997). We followed the terminology of Stoops (2003) to define soil micromorphological characteristics.

Quartz is one of the most persistent coarse mineral components of soils. Surface features of quartz grains in the soils are indicative of the mechanisms 
of sediment transport as well as of breakdown by cryogenic processes and of chemical dissolution. We extracted under binocular medium sand-size quartz particles from the samples collected in the profile under moss (upper organo-mineral $\mathrm{HB}$ and lower mineral BC horizons, 20 grains from each) and studied their surface morphology under the scanning electron microscope Hitachi S-806. Identification and further genetic interpretation of the quartz grain surface features was done using the atlas by Krinsley and Doornkamp (1973).

\subsection{RADIOGARBON DATING OF SOM}

Total organic carbon (TOC) was earlier dated by radiocarbon method. The radiocarbon dates were obtained by accelerator mass-spectrometry (AMS). Graphite ${ }^{14} \mathrm{C} /{ }^{13} \mathrm{C}$ ratios were measured using the CAIS $0.5 \mathrm{MeV}$ accelerator mass spectrometer. The sample ratios were compared to the ratio measured from the Oxalic Acid II (NBS SRM 4990C). The quoted uncalibrated dates have been given in radiocarbon years before 1950 (years $\mathrm{BP}$ ), using the ${ }^{14} \mathrm{C}$ half-life of 5568 years. The details of the dating technique and processing of results were presented earlier (Zazovskaya et al., 2017), here we discuss the significance of SOM radiocarbon ages in the context of micromorphology of organic components.

\section{Results}

\subsection{SOIL PROFILES: LANDSGAPE SETTING, MORPHOLOGY, OUTLINE OF THE ANALYTICAL GHARAGTERISTICS}

The objects of the present study were the soil profiles at the 'Chernoe Lake' site $\left(70^{\circ} 45\right.$ 45,123 $\mathrm{S} 11^{\circ} 4651,414 \mathrm{E}$ ) located within a closed hollow of that small lake. The soil pits were positioned at a distance of $5 \mathrm{~m}$ from the lake's water edge, in close proximity to the edge of the snow patch (Figure 3). Mosses had a percentage cover of 90-95\%. The main typical moss species for such habitats were identified as follows: Bryum archangelicum, Bryum pseudotriquetrum, Ceratodon purpureus and Coscinodon lawianus (Kurbatova and Ochyra, 2012). Crustose lichens occupied soil surface near mosses and sometimes occurred over dead tufts of moss, most common species are: Umbillicaria decussate and Lepraria membranacea. The size of their colonies is rather small with a maximum of $2-3 \mathrm{~cm}^{2}$.

A typical profile of the soil under moss was characterized by the following sequence of horizons:

$\mathrm{O}_{\mathrm{i}}$ - the litter horizon, $1.5-2.5 \mathrm{~cm}$ thick, composed of moss fragments, both alive and dead, but retaining their anatomic structure, enriched in mineral sand grains;

$\mathrm{H}_{\mathrm{i}}$ - the dry peat horizon, up to $3 \mathrm{~cm}$ thick, also rich in sandy mineral material, fragmentary represented by lenses and pockets;

$\mathrm{HB}$ - the organo-mineral horizon, 3-5 $\mathrm{cm}$ thick, with sandy texture, contains alive and dead moss rhizoids. Fills the spaces between lenses/ pockets of the $\mathrm{H}$ horizon;

$\mathrm{BC}$ - the mineral horizon, with reddish brown films on some sand-sized grains; underlain by permafrost.

A total thickness of the soil profiles under mosses varied from 8-10 to $25-30 \mathrm{~cm}$.

Under lichens the set of organic horizons is reduced to just the surface $\mathrm{O}_{i}$ horizon of few millimeters underlain by $\mathrm{HB}$ and $\mathrm{BC}$ horizons.

Sand-sized grains of light-coloured minerals free from iron hydroxide films frequently occurred within the $\mathrm{O}_{\mathrm{i}}, \mathrm{H}_{\mathrm{i}}$ and $\mathrm{HB}$ horizons. These bleached grains occasionally formed thin layers and lenses directly below $\mathrm{H}_{i}$. Peat-like residues of mosses were often present in form of small lenses within the HB horizon and the mineral BC horizon. The soils were classified as Turbic Cryosols.

It has been established by the authors (Zazovskaya et al., 2015) that the organic carbon contents in the soils studied are as follows: $2.7-13.6 \%$ in the litter $\left(\mathrm{O}_{\mathrm{i}}\right)$ horizon, $0.4-2.1 \%$ in the $\mathrm{HB}$ horizon, and $0.02-0.25 \%$ in the $\mathrm{BC}$ horizon. Most of the organic matter is weakly bound with the mineral matrix, weakly humified and represented by labile, available compounds. The $\mathrm{pH}$ of water extract 

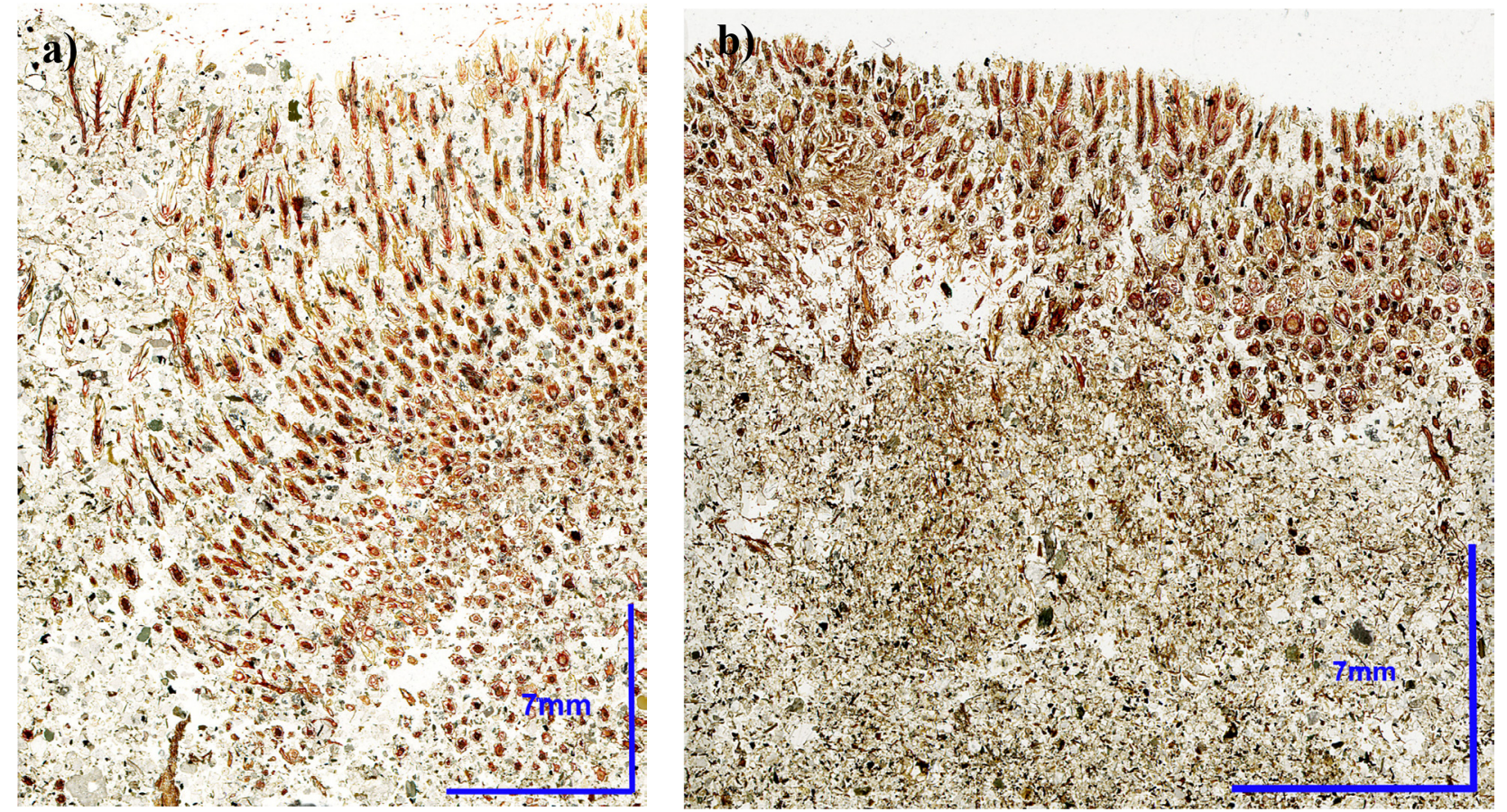

Figure 4 Landscape setting and profile morphology of studied soils; the red frame shows part of the profile from where undisturbed soil block was taken.

tends to uniformly increase with depth, while the $\mathrm{pH}$ of $\mathrm{KCl}$ extract has a different profile distribution with its minimal values being found in the mineral or organo-mineral horizons and corresponding to medium and strongly acid reaction. The residual acidity decreases with depth, with its values in the organogenic horizons being 10 times as high as those in the mineral horizons. The degrees of base unsaturation of the soil exchange complex are as follows: $22-33 \%$ in organogenic $\mathrm{O}_{i}$ and $\mathrm{H}_{i}$ horizons, $34-45 \%$ in the $\mathrm{HB}$ horizon, $38-56 \%$ in the mineral horizons and $8-39 \%$ in the parent material. The upper part of the profile is characterized by biogenic accumulation of bulk phosphorus, sulphur, calcium, magnesium, iron and manganese. The bulk $\mathrm{K}_{2} \mathrm{O}$ contents have a relatively uniform distribution, but mobile forms of potassium are accumulated within the upper horizons: 18-28 mg/100 $\mathrm{g}$ in the litter and 7-19 mg/100 $\mathrm{g}$ in the HB horizon. A high bulk content of $\mathrm{CaO}(5-6 \%)$ is connected with a high proportion of plagioclases in the mineralogical composition and a weak manifestation of leaching processes. The contents of dithionite-extractable $\mathrm{Fe}_{2} \mathrm{O}_{3}$ in the moss-covered soils are $0.23-0.39 \%$ in the mineral horizons and $0.42-0.48 \%$ in the organogenic horizons, being similar to those in sandy bare grounds. The contents of oxalate-extractable $\mathrm{Fe}_{2} \mathrm{O}_{3}$ in moss-covered soils are significantly higher than those in bare grounds, which results from the processes of iron mobilization in the course of pedogenesis. The maximal contents of both dithionite- and oxalate-extractable iron are observed in the upper part of soil profile and likely have a biogenic origin. The maximal concentrations of amorphous iron are found in the lower part of soil profile in combination with reddish brown coatings on some sand-sized grains, which is an indication of weakly developed processes of illuviation of iron and, possibly, other elements in some profiles. The radiocarbon age of the organic matter of humified peaty horizons or the lower (peaty) part of the litter of the soils studied under moss-lichen cover varies within a range of 250-400 years. The radiocarbon dates obtained for the soils under moss communities show a gradual increase 
in the radiocarbon age with depth, with the pMC (percent Modern Carbon) of $100 \%$ in the upper peaty horizons; the latter have the functioning period of 50-60 years, which increases up to 400 years in the $\mathrm{B}$ horizons of soils formed under moss communities (Zazovskaya et al., 2017).

\subsection{SOIL MIGROMORPHOLOGY}

In thin sections the material of all samples is made up of mineral and organic particles, loosely packed, with abundant packing voids. The proportions of the two main constituents are variable, the samples from soils under lichens (1 and 2) are dominated by the mineral material, in the soils under mosses (3 and 4) portions are comparable with uniform distribution of organic material (Figure 4a), in the sample 5 the proportion varies within the sample, organic matter quickly decreases with depth (Figure $4 \mathrm{~b}$ ). Single-grain structure is predominant, larger peds are absent.

Mineral components of all studied samples consist mostly of the coarse grains with angular shape, which consist predominantly of sand with an admixture of fine gravel, whereas silt particles are scarce. Their mineralogical composition includes quartz, K-feldspars, Na-plagioclases, biotite, garnet, and larger (gravel) particles of gneiss fragments. All these minerals appear fresh with the exception of biotite; the latter in the samples 1 and 2 has typical signs of alteration which consist of fracturing and exfoliation along the cleavage planes and deformation of the laminae close to the edges (so-called frayed edges) (Figure 5a). In some larger rock fragments brownish clusters of clay minerals, which partially substitute feldspars and also occupy spacings between primary minerals was observed (Figure 5b). The distribution of coarse particles of different sizes is sometimes non-uniform: in the samples 1 and 2 we observed rounded or lenticular clusters of the coarse sand and gravel, neighbouring with the concentrations of medium and fine sand (Figure 5c).

Fine material is present in minor quantities. In all samples (but more developed in 1 and 2) it forms thin discontinuous but quite frequent films on the sand and gravel surfaces (chitonic c/f related distribution pattern). Brown colour of these films (Figure 5d) and clear yellowish interference colours (Figure 5e) observed under crossed polarisers point to their predominantly clayey composition with some ferruginous pigment.

Organic components are represented predominantly by fresh or slightly decomposed tissue fragments of mosses and lichens, with preserved cellular structure (Figure 5f) and in the case of mosses - interference colours in some loci. However, in the samples 4 and 5 we observed in some areas the signs of degradation of the moss tissues: their colour becomes darker, cellular structure is lost, and colloidal dark humus material is formed. The latter forms dark isotropic coatings on the sand mineral grains (Figure $5 \mathrm{~g}$ ) sometimes above the anisotropic clay coatings; this type of coatings is however restricted to the micro-areas in the vicinity of the decomposing moss tissues.

The most spectacular observations are related to the interaction of the organic and mineral components, which together form a highly organised architecture of the groundmass. In the samples 1 and 2 the horizontally oriented lichen thalli cover and trap the mineral sand grains, to produce the compound porous crusts up to $0.5-0.8 \mathrm{~mm}$ thick (3-4 sand particles) (Figure 5h). Conspicuously birefringent iron-clay films on sand grains within these crusts tend to be thicker than in the rest of the groundmass.

In samples 3 and 4 the fresh tissues of the mosses develop a kind of net, in the meshes of which loose mineral sandy material is trapped (Figure 5i). The same net structure is also observed in the upper $2 \mathrm{~cm}$ of the sample 5, whereas below more abundant mineral material is mixed with few and decomposed moss tissue fragments (Figure 5j).

Under scanning electron microscope, the absolute majority of quartz grains from the profile under moss vegetation showed angular outline and sharp edges. The grain surfaces combine the conchoidal breakage pattern with cleavage plates. The conchoidal fractures demonstrate pronounced straight 

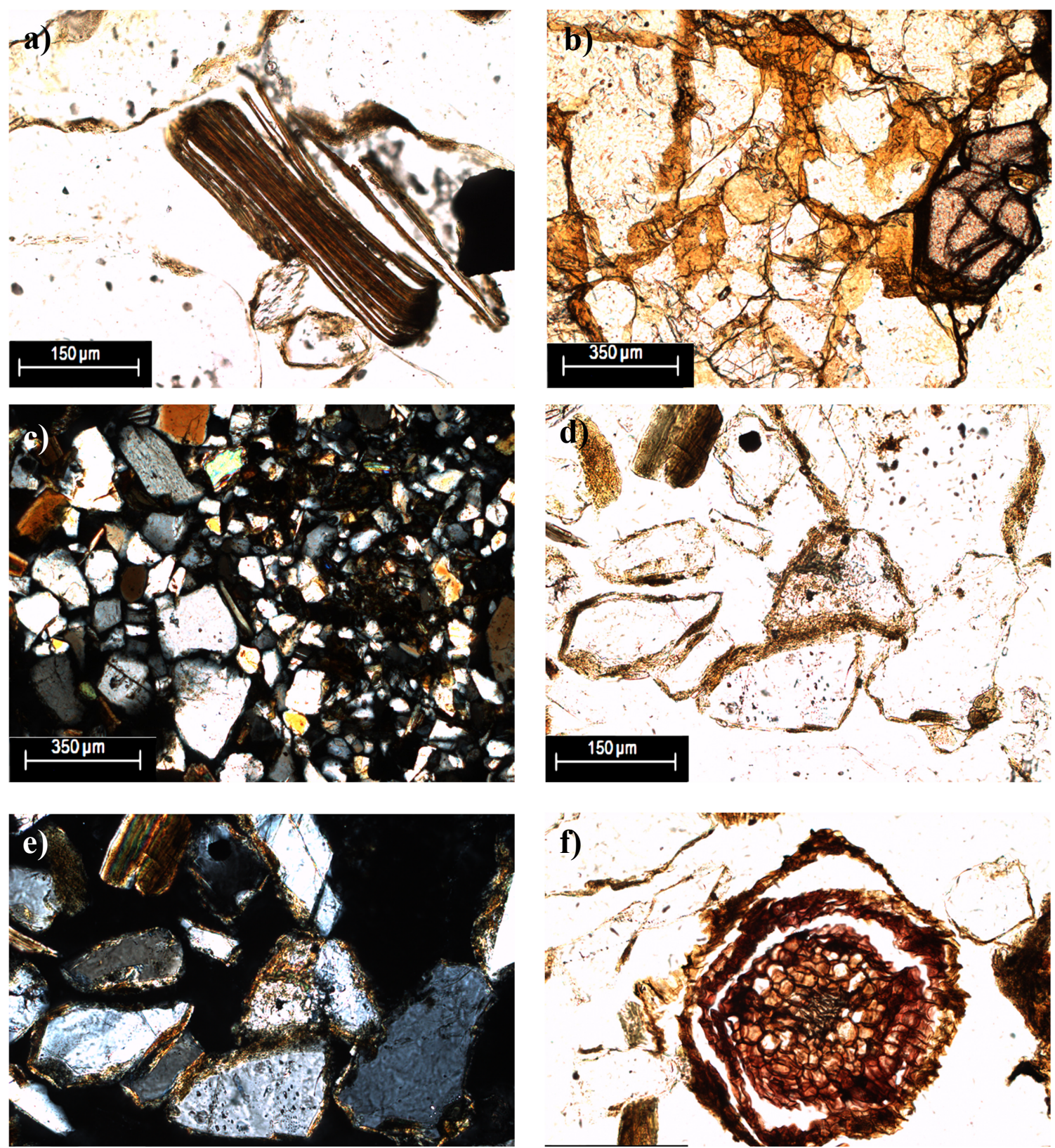

Figure 5 Micromorphology of soils of Schirmacher oasis. PPL: plain polarized light; N+: crossed polarizers. a) Altered grain of biotite, profile 1, PPL; b) yellow-brown clay material in the gneiss fragment, profile 1, PPL; c) clusters of coarse (left) and fine sand material, profile $1, \mathrm{~N}+$; d) iron-clay coatings on sand grains, profile 2, PPL; e) same as d), N+; f) fragment of moss tissue with preserved cellular structure, profile 3, PPL. Continued on the next page.

and arcuate steps (Figure 6a). Some fresh cracks are dissecting the step surfaces (Figure 6b), in other cases thin fissures sub/parallel to the grain surface are separating thin platy flakes resulting in a "microdesquamation" (Figure 6c). We observed clear etching pits on some grains, concentrated predominantly at the limits between breakage blocks (Figure 6d). The breakage features: the conchoidal surface pattern with steps, cracks and fissures have maximal development in the quartz 

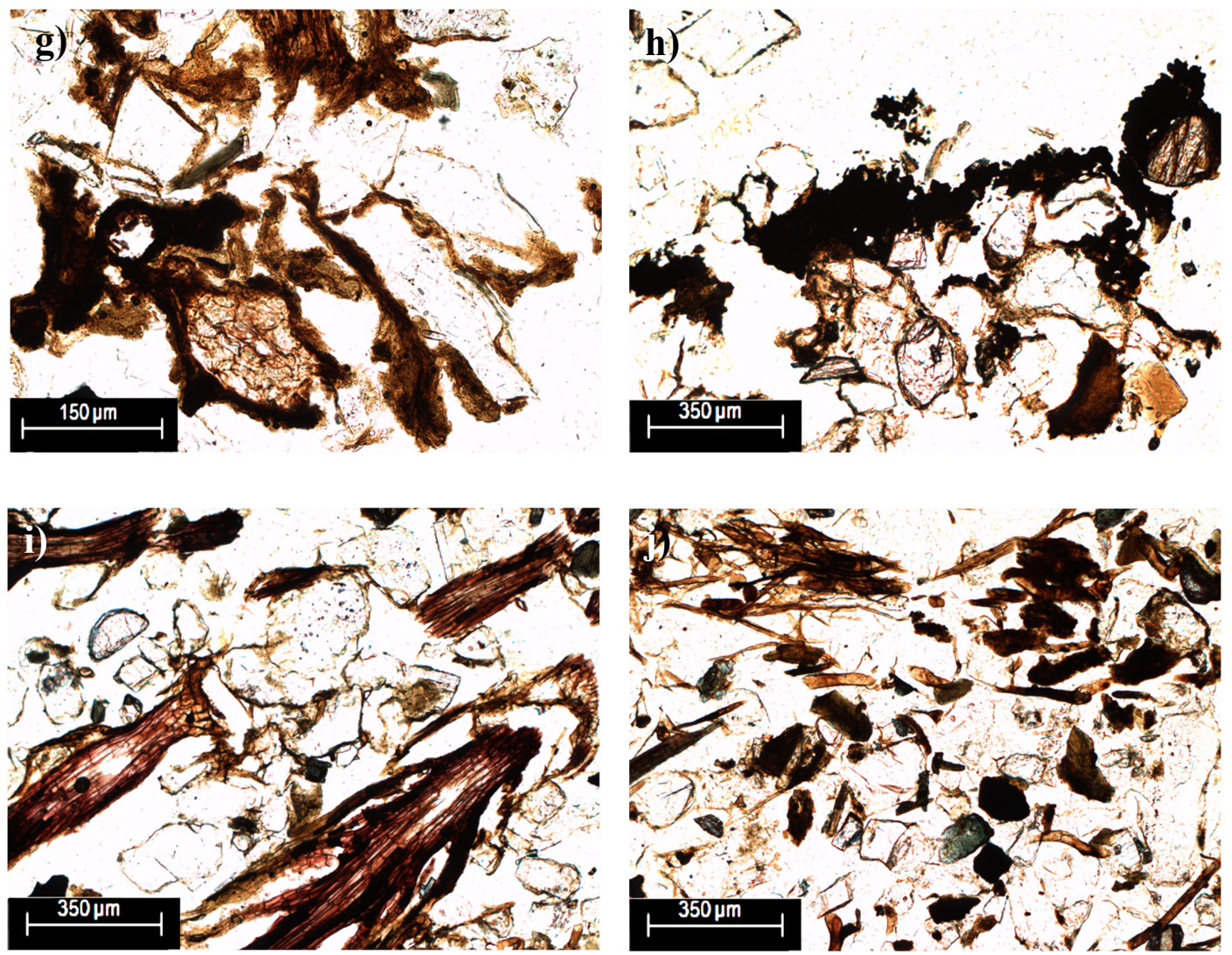

Figure 5 (Continuation) Micromorphology of soils of Schirmacher oasis. PPL: plain polarized light; N+: crossed polarizers. g) Dark organic coating on sand srain near decomposed plant tissue, profile 3, PPL; h) biological crust formed by lichen, profile 2, PPL; i) mineral grains trapped among moss tissues, profile 3, PPL; h) mineral material mid with partly decomposed organic fragments, profile 5, PPL.

grains of the surface horizon, whereas the etching pits are more frequently observed on quartz of the deeper part of the profile.

\section{Discussion}

\subsection{TRANSFORMATION OF MINERAL AND ORGANIC COMPONENTS: MICROSCOPIC FEATURES AND THEIR LINKS WITH ANALYTICAL DATA}

The mineralogical composition of sedimentary parent material for the studied soils resembles that of the source rocks - Precambrian gneiss. This agrees with the results of Srivastava et al. (2010) on the heavy mineral assemblages from the Schirmacher Oasis sediments which correspond to the local metamorphic bedrock and demonstrate low maturity. In general, that is typical for the sediments, generated within the glacial geosystems (Nesbitt and Young, 1996), where sediment composition is controlled by physical breakdown and fluvial sorting with minimal contribution of biochemical weathering (Caracciolo et al., 2012). However, in the soil environment the primary minerals are subjected to a complex set of alteration processes manifested by clear micromorphological features and reflected in soil properties.

Quartz grains demonstrate numerous surface microstructures, which are related to the cryogenic fragmentation and in various occasions were observed in multiple freezing experiments and in the sediments strongly affected by frost action (Rogov, 2000). These microstructures are registered in the granitic regolith, developed under effects of freezing/thawing cycles in continental cold regions of Siberia (Gurinov et al., 2015). Very similar features are known to be diagnostic 
in general for the glacial sediments (Krinsley and Doornkamp, 1973). The question arises, if the observed quartz morphologies are a product of the recent cryogenic fragmentation or rather a relict derived from glacial material, left behind after deglaciation of the oasis in the early Holocene. Shmelev (2015), who studied evidence of cryogenic weathering (including quartz surface indicators) in a thick sediment sequence of Larsemann oasis stated that maximum development is registered in the glacial sediments corresponding to MIS2/Last Glacial Maximum. We, however, doubt the inherited nature of the quartz surface features in our case. The quartz grains in the thin soils of Schirmacher Oasis were clearly redeposited recently - possibly in multiple pushes - by the fluvial processes caused by meltwater surface runoff with possible participation of eolian transport (although clear eolian grain surface features have not been observed). This transport is expected to obliterate at least partly the cryogenic forms if the latter were inherited, however they look very fresh. Also their higher frequency in the surface horizon where alternation of freezing and thawing is most frequent points to their contemporary in situ (post-deposition) development. Intensive present day cryogenic breakdown of quartz on the surface of granitic outcrops was shown in other regions of Antarctica (French and Guglielmin, 2000).

More conspicuous is the evidence of chemical weathering (although relatively weak), observed on some quartz grains but most evident in the micromorphology of biotite flakes, which shows well known alteration pattern (Bisdom et al., 1982). We should stress that the latter features most probably developed in situ and are not inherited: the altered biotite has so delicate and fragile features that even short-distance transportation of pre-weathered grains is highly improbable. Our data are not unique: Wentworth et al. (2005) also report the signs of silicate weathering in the soils of Antarctic dry valleys, including typical serrated edges of amphiboles, while Guglielmin et al. (2005) found microscopic traces of biochemical weathering in the granites of the Northern Victoria Land. These findings were quite unexpected for the severe soil environment characterised by low temperatures, precipitation, biological activity and even rather short period when liquid water - the main agent of chemical alteration - is available.

We think that aggressive metabolites produced by mosses and lichens could switch on silicate alteration even under unfavourable climatic conditions of Eastern Antarctica. The weathering efficiency of these primitive organisms in general is considered to be inferior in comparison with higher vascular plants (Berner, 1997) especially those with developed mycorrhiza (Quirk et al., 2012). On the other hand the field studies (Jackson, 2015) as well laboratory microcosm experiments (Lenton et al., 2012) demonstrated that the presence of lichens and mosses enhances the chemical decomposition of rocks by one or more orders of magnitude as compared to abiotic conditions. This effect was observed in a vast variety of environments including severe arctic alpine ecosystems (McCarroll and Viles, 1995). In Antarctica the role of the endolithic lichens for physical and chemical weathering of massive rocks was shown e.g. by Chen and Blume (2002) and Mergelov et al. (2012).

The principal factor of chemical weathering enhancement by these primitive plants is generation of aggressive acid metabolites (Chen et al., 2000). The effect of the substances produced by these organisms could be very strong on the microscopic scale (Banfield et al., 1999), in the area of direct contact between living tissues and mineral surfaces, within biofilms. It is known for example that cyanobacteria in a biofilm on a mineral surface could lower $\mathrm{pH}$ values down to 3-4 (Ríos et al., 2003) whereas in other cases these microorganisms elevated $\mathrm{pH}$ up to 9, thus enhancing quartz dissolution (Brehm et al., 2005). Etching of primary minerals including quartz as a result of Calabrian granodiorite weathering by lichens was demonstrated by Scarciglia et al., (2012). Similar conditions could develop in the organo-mineral crust which we observed in thin sections where lichen tissues surround mineral sand grains. These processes occurring on microscale near soil surface 
could have an effect within the whole soil body, due to permanent aggradation (as discussed below). Taking into account relative abundance of biotite in the local granitic rocks, we consider weathering to be responsible for the accumulation of mobile potassium and the dithionite- and oxalate-extractable iron in these soils, as far as biotite alteration is accompanied by release of both these elements from its interlayer and lattice. Biotite alteration is also the most important producer of iron-clay fine material in the studied soils. In the long run these weak but persistent weathering processes in the syn-sedimentary soils should also influence the mineralogical composition of sediments after multiple re-deposition stages. Robinson and Johnsson (1997) detected the impact of chemical alteration in the mineralogy of fluvial deposits in the cold arctic environment at the North slope of Alaska; they attributed it to the organic acid activity in the tundra soils which affect sedimentary material during the alluvial storage. On the regional scale this influence is visible in the clay mineral composition of the Schirmacher Oasis sediments studied by Srivastava et al. (2011): the samples from the lake margins have shown a high proportion of illite and presence of vermiculite that are most probably the products of recent biotite alteration in the soil environment.

The other possible sources are brownish clusters of clay material which we observed inside some gneiss fragments. Abakumov et al. (2013) also noticed fine materials in the fissures of rock fragments in the West Antarctica and interpreted them as the products of recent pedogenesis. In our case we are quite convinced of the relict nature of these materials, inherited from of ancient weathering (or postmagmatic/hydrothermal processes), as far as they are found only inside some fragments and not on their surface. In the course of cryogenic fragmentation these materials are liberated from their host rock and mineral particles and incorporated into micromass. This process could be of major importance for clay accumulation in some coarse-textured soils (Sedov and Shoba, 1996). In the studied profile the small amount of available iron-clay fine material forms coatings on the coarse sand grains. We think that this distribution is most "profitable" for performing ecosystem functions of these quite scarce components. Thusly, they have more extensive contact with the percolating water and could absorb part of it. They are more accessible for microorganisms, lichens, rhizoids of mosses, supplying them with the absorbed nutrients. Thus the iron-clay coatings could provide microhabitat for various primitive organisms that colonise these substrates and are the key mineral component for generating biofilms.

Micromorphological observations have shown that organic materials are present in these incipient soil bodies mostly in the form of relatively fresh lichen and moss fragments with the tissue microstructure still preserved. Colloidal decomposed organic matter is formed only in minor quantities. Very similar micromorphological observations about organic components were made in the Lithosols of Western Antarctica (Vlasov et al., 2005), including findings of organic coatings on coarse mineral grains (Abakumov et al., 2013). However, radiocarbon dating of the organic material in these profiles has produced ${ }^{14} \mathrm{C}$ ages in the range from dozens to 1000 yr BP (Zazovskaya et al., 2017). We conclude that undecomposed organic materials could persist in these extreme cold landscapes with the residence times of hundreds of years, despite limited moisture and predominantly oxidative soil environment. This conclusion could be meaningful for modelling of the current carbon budget in Antarctic oasis ecosystems. It also could have implications for reconstructions of the past carbon cycle and climatic change. In particular, it supports the "permafrost glacial hypothesis" of Zech (2012), which postulates gradual sequestration of organic carbon in the permafrost soils during the Pleistocene cold periods (glaciations/cryochrons). In fact, during these periods, characterized by cooling, extension of permafrost and activation of 

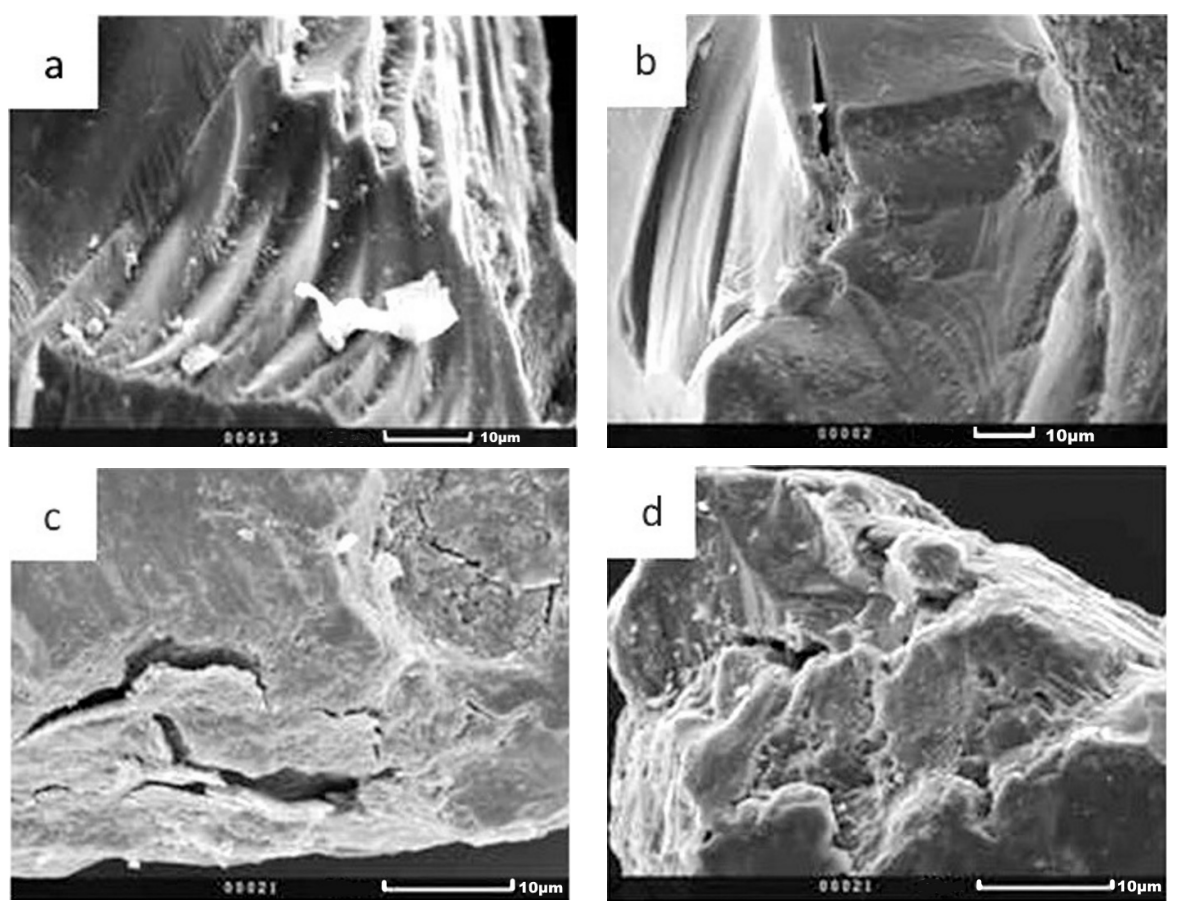

Figure 6 Electron microscopy of quartz grains surfaces from the soils of Schirmacher Oasis. a) conchoidal pattern with arcuate steps; b) crack dissecting the step; c) thin cracks parallel to the grain surface; d) etching pits at the limits of breakage blocks.

surface geomorphic processes, incipient syn-sedimentary soils under moss and lichen cover (similar to those of Antarctic oases) should have occupied vast territories. Our data confirm that despite their poor development these soils could store organic matter mostly in the form of the fresh plant tissues. This form appears to be quite persistent under cold dry climate, however should readily decompose in case of warming - in agreement with the hypothesis of Zech (2012).

\subsection{INTERACTION OF MINERAL AND ORGANIC COMPONENTS: A MEGHANISM OF SOIL AGGRADATION IN THE EXTREME GOLD ENVIRONMENT}

The most interesting micromorphological observations are related to the interaction of the organic tissues and mineral material. As mentioned above we observed formation of discontinuous microscopic crusts in which the organic material of lichens surrounds and binds together the sand particles. In fact, this object corresponds to a species of "biological soil crust" (Belnap and Lange,
2003). The fact that we found these crusts not only on the surface but also inside the soil matrix could be explained by their regular burial with a new portion of sediments (although in some cases the sub-surface development of endolithic lichen species is possible). Each time however the lichens form the new crust which seals the surface, binds the mineral grains together and thus diminishes further particle mobility; extracellular polymeric substances could also participate in forming connections between the mineral particles (Souza-Egipsy et al., 2004). Similar effects of lichen soil crusts on erosion and deposition were documented micromorphologically by Eldridge (1998) in the soils disturbed by grazing of Australia. Thus biological soil crusts (both active on the surface and buried) trap the transported mineral material and provide development of relatively thick syn-sedimentary soil layer.

Even more evident is the trapping effect of the moss tissues. As we observed in the thin sections, they develop a network of variable density throughout the whole upper horizon. Mineral 
grains occupy the "meshes" of the moss net. The supposed mechanism of formation of such structure is permanent retention of the transported mineral sediment among growing mosses. It seems that such structures are relatively common: the micromorphological image of the "biological soil crust composed of mosses" on a sandy soil in the Inner Mongolia published by Pagliai and Stoops (2010) is very similar to ours. Thus the described mechanism of sediment stabilization and development of incipient syn-sedimentary soils is relatively common in the landscapes with high geomorphic activity (due to severe climatic conditions or to anthropogenic disturbance). This mechanism could have certain implications for reconstructing past sedimentation processes in the extreme geomorphologically active terrestrial environments. As we discussed above the analogues of the incipient syn-sedimentary Antarctic soils formed under mosses and lichens should expand considerably during the cold periods of the Quaternary. Recently Svirčev et al., (2013) formulated the "biological crust model" of loess formation during the Pleisticene glaciations. The model which these authors propose for the loess accumulation in the past is quite similar to our scheme of the contemporary soil aggradation in Antarctic oasis. Thus the latter phenomenon could be judged as a local "recent analogue" of the large-scale Pleistocene sedimentation process. The syn-sedimentary soils/biological crusts of Antarctic oases could serve as a recent analogue also for the modelling of pedogenesis of more distant geological past, before the emergence of the vascular plants in the Devonian. Campbell (1979) considered biological crust mechanism of soil accretion and stabilization due to the effect of cyanophyte mat to be an important Precambrian surface process. In the early Paleozoic the shallow soils/biological crusts under non-vascular plants (bryophites) could also have been similar to the soils of Antarctic Oasis, especially those preceding and persisting during the cold glacial phases in the end of Ordovician (Lenton et al., 2012).

\section{Conclusions}

1) Micromorphological analysis of the incipient soils in the oasis of East Antarctic developed under moss and lichen communities on the recent sediments derived from gneiss revealed signs of cryogenic breakdown of quartz grains accompanied by chemical alteration of silicates, especially biotite. Weathering together with incorporation of inherited clayey components gave rise to moderate accumulation of iron-clay fine material, which tended to coat the sand grains of primary minerals.

2) Organic matter accumulates in the studied soils mostly in form of poorly decomposed tissue fragments of mosses and lichens. Decomposition is observed in a few micro-areas being accompanied by precipitation of dark colloidal organic substances forming isotropic coatings on sand sometimes overlying anisotropic clay films. Radiocarbon dates of SOM indicate preservation of these poorly decomposed plant residues at least during hundreds of years.

3) Organic and mineral components interact in the surface organo-mineral horizon/biological soil crust, in which lichen and moss tissues form a framework in which mineral grains are bound and stabilized; the formation of the crust hampers further mobilization of grains by erosional processes, whereas deposition of new portion of sediment and formation of biogenic crust on the new surface promotes soil aggradation.

4) The syn-sedimentary soils of Antarctic oases could be considered as a modern analogue for the soils of the Pleistocene glacial periods characterized by extension of cold dry landscapes with high 
activity of cryogenic and geomorphic processes, as well as for the soil development during Precambrian and early Paleozoic, before the emergence of the higher plants.

\section{Acknowledgements}

Investigations were partly financially supported by the Russian Science Foundation, project No.14-27-00133 (analytical results) and by the Russian Foundation for Basic Research, project No. 17-04-01475 (investigations of organomineral interactions). The field works were supported by the Russian Antarctic Expedition. We are grateful to Jaime Díaz (UNAM) for preparing soil thin sections.

\section{References}

Abakumov, E.V., 2010, The sources and composition of humus in some soils of West Antarctica: Eurasian Soil Science, 43(5), 499-508.

Abakumov, E.V., Gagarina, E.I., Sapega, V.F., Vlasov, D.Y., 2013, Micromorphological features of the fine earth and skeletal fractions of soils of west Antarctica in the areas of Russian Antarctic stations: Eurasian Soil Science, 46(12), 1219-1229.

Asthana, R., Chaturvedi, A., 1998, The grain size behaviour and morphoscopy of supraglacial sediments, south of Schirmacher Oasis, E. Antarctica: Journal of the Geological Society of India, 52(5), 557-568.

Asthana, R., Shrivastava, P.K., Beg, M.J, Swain, A.K., Dharwadkar, A., Roy, S.K., Srivastava, H.B., 2013, Sedimentary processes in two different polar periglacial environments: Examples from Schirmacher Oasis and
Larsemann Hills, East Antarctica, in Hambrey, M.J., Barker, P.F., Barrett, P.J., Bowman, V., Davies, B., Smellie, J.L. Tranter, M. (eds.), Antarctic Palaeoenvironments and Earth-Surface Processes: London, The Geological Society of London, Special Publications, 381, 411-427.

Balks, M.R., López-Martínez, J., Goryachkin, S.V., Mergelov, N.S., Schaefer, G., Simas, F.N.B., Almond, P.C., Claridge, G.G.C., Mcleod, M., Scarrow, J., 2013, Windows on Antarctic soillandscape relationships: comparison across selected regions of Antarctica, in Hambrey, M.J., Barker, P.F., Barrett, P.J., Bowman,V., Davies, B., Smellie, J.L. Tranter, M. (eds.), Antarctic Palaeoenvironments and EarthSurface Processes: London, The Geological Society of London, Special Publications, 381, 397-410.

Banfield, J.F., Barker, W.W., Welch, S.A., Taunton, A., 1999, Biological impact on mineral dissolution: Application of the lichen model to understanding mineral weathering in the rhizosphere: Proceedings of the National Academy of Sciences of the United States of America, 96(7), 3404-3411.

Belnap, J., Lange, O.L., 2003, Biological Soil Crusts: Structure, Function, and Management: Berlin, Germany, SpringerVerlag, 506 p.

Berner, R.A., 1997, The rise of plants and their effect on weathering and atmospheric $\mathrm{CO}_{2}$ : Science, 276(5312), 544-546.

Beyer, L., 2000, Properties, formation, and geoecological significance of organic soils in the coastal region of East Antarctica (Wilkes Land): Catena, 39(2), 79-93.

Beyer, L., White, D.M., Pingpank, K., Bölter, M., 2004, Composition and transformation of soil organic matter in Cryosols and Gelic Histosols in coastal eastern Antarctica (Casey 
Station, Wilkes Land), in Kimble, J.M. (ed.), Cryosols: Berlin, Germany, Springer, 525-556.

Bisdom, E.B.A., Stoops, G., Delvigne, J., Curmi, P., Altemuller, H.J., 1982, Micromorphology of weathering biotite and its secondary products: Pedologie, 32(2), 225-52.

Blakemore, L.C., Swindale, L.D., 1958, Chemistry and clay mineralogy of a soil sample from Antarctica: Nature, 182, 47-48.

Blume, H.P., Bölter, M., 1992, Soils at Casey Station (Wilkes Land, Antarctica), in Gilichinsky, D. (ed.), Proceedings First International Conference of Cryopedology: Pushchino, Russia, Russian Academy of Sciences, 96-103.

Bockheim, J.G., 1995, Permafrost distribution in the Southern Circumpolar Region and its relation to the environment: a review and recommendations for further research: Permafrost and Periglacial Processes, 6(1), $27-45$.

Bockheim, J.G., 1997, Properties and classification of Cold Desert soils from Antarctica: Soil Science Society of America Journal, 61(1), 224-231.

Bockheim,J.G. (ed.), 2015, The Soils of Antarctica: Switzerland, Springer International Publishing, $322 \mathrm{p}$.

Bockheim, J.G., Ugolini, F.C., 1990, A review of pedogenic zonation in well-drained soils of the Southern Circumpolar Region: Quaternary Research, 34(1), 47-66.

Bormann, P., Fritzsche, D. (eds.) 1995, The Schirmacher Oasis, Queen Maud Land, East Antarctica, and its surroundings: Gotha, Germany, Justus Perthes, 448 p.

Brehm, U., Gorbushina, A., Mottershead, D., 2005, The role of microorganisms and biofilms in the breakdown and dissolution of quartz and glass: Palaeogeography, palaeoclimatology, palaeoecology: 219(1-2), 117-129.

Campbell, I.B., Claridge, G.G.C., 1987, Antarctica: Soils, weathering processes and environment: Amsterdam, The Netherlands, Elsevier Science, 367 p.

Campbell, S.E., 1979, Soil stabilization by a prokaryotic desert crust: implications for Precambrian land biota: Origins of Life and Evolution of Biospheres, 9(4), 335-348.

Caracciolo L., Tolosana-Delgado, R., Le Pera, E., von Eynatten, H., Arribas, J., Tarquini, S., 2012, Influence of granitoid textural parameters on sediment composition: Implications for sediment generation: Sedimentary Geology, 280(1), 93-107.

Chen, J., Blume H.P., 2002, Rock-weathering by lichens in Antarctic: patterns and mechanisms: Journal of Geographical Sciences, 12(4), 387-396

Chen, J., Blume, H.-P., Beyer, L., 2000, Weathering of rocks induced by lichen colonization - a review. Catena, 39(2), 121-146.

Claridge, G.G.C., 1965, The clay mineralogy and chemistry of some soils from the Ross Dependency, Antarctica: New Zealand Journal of Geology and Geophysics, 8(2), $186-220$

Eldridge, D.J., 1998, Trampling of microphytic crusts on calcareous soils and its impact on erosion under rain-impacted flow: Catena, 33(3-4), 221-239.

FAO, 2006, Guidelines for soil description: Rome, Italy, Food and Agriculture Organization of the United Nations, $97 \mathrm{p}$.

Fedorov-Davydov, D., Lupachev, A., Zazovskaya, E., Mergelov, N., Osokin, N., Dolgikh, A., Abramov, A., Ivashchenko, A., Zamolochikov, D., Karelin, D., Shmelev, D., Krivushin, K., Mironov, V., 2013, Soil Temperature Regime in the Areas of Russian Antarctic Stations (abstract), in 6th International Conference on Cryopedology "Frost-affected soils dynamic soils in the dynamic world: Krakow, Poland, Institute of Geography and Spatial Management, Jagiellonian University, IUSS Working Groun Cryosols, Polish Society of Soil Science, 11. 
French, H.M., Guglielmin, M., 2000, Cryogenic weathering of granite, Northern Victoria Land, Antarctica: Permafrost and Periglacial Processes, 11(4), 305-314.

Gilichinsky, D., Abakumov, E., Abramov, A., Fyodorov-Davydov, D., Goryachkin, S., Lupachev, A., Mergelov, N., Zazovskaya, E., 2010, Soils of Mid and Low Antarctic: diversity, geography, temperature regime (abstract), in Gilkes, R.J., Prakongkep, N. (eds.), Proceedings of the 19th World Congress of Soil Sciences, Soil Solutions for a Changing World: Brisbane, Australia, IUSS, 32-35.

Glazovskaya, M. A., 1958, Weathering and Initial Soil Formation in Antarctica: Nauchnye Doklady Vysshei Shkoly, Geologiya i Geografiya Nauki, 1, 63-76.

Gore, D., Pickard, J., 2007, Antarctic Oases, in Riffenburgh, B. (ed.), Encyclopedia of the Antarctic: New York, U.S.A., Routledge, 679-680.

Goryachkin, S.V., Gilichinskii, D.A., Mergelov, N.S., Konyushkov, D.E., Lupachev, A.V., Abramov, A.A., Zazovskaya, E.P., 2012, Soils of Antarctica: First Results, Problems, and Prospects of the Study, in Kasimov, N.S., Gerasimova, M.I. (eds.), Geochemistry of Landscapes and Soil Geography (on the 100th Jubilee of M.A. Glazovskaya): Moscow, Russia, 365-392.

Guglielmin, M., Cannone, N., Strini, A., Lewkowicz, A.G., 2005, Biotic and abiotic processes on granite weathering landforms in a cryotic environment, Northern Victoria Land, Antarctica: Permafrost and Periglacial Processes, 16(1), 69-85.

Gurinov, A.L., Lukashov, A.A., Rogov, V.V., Kurchatova, A.N., Lebedeva-Verba, M.P., 2015, Weathering of the Adun-Chelon granite, Transbaikalia: Kriosfera Zemli, 19(3), 34-38.
IUSS Working Group WRB, 2015, World Reference Base for Soil Resources 2014, update 2015, International soil classification system for naming soils and creating legends for soil maps: Rome, Italy, Food and Agriculture Organization of the United Nations, World Soil Resources Reports, 106, $192 \mathrm{p}$

Jackson, T.A., 2015, Weathering, secondary mineral genesis, and soil formation caused by lichens and mosses growing on granitic gneiss in a boreal forest environment: Geoderma, (251/252), 78-91.

Jensen, H.I., 1916, Report on Antarctic soils: British Antarctic Expedition, 1907-1909, Part IV, Geology, 2, 89-92.

Krinsley, D.H., Doornkamp, J.C., 1973, Atlas of quartz sand surface textures: Cambridge, G.B., Cambridge University Press, 102 p.

Kurbatova, L.E., Ochyra, R., 2012, Two noteworthy additions to the moss flora of the Schirmacher oasis in continental Antarctica: Cryptogamie Briologie, 33(2), 159-167.

Lenton, T.M., Crouch, M., Johnson, M., Pires, N., Dolan L., 2012, First plants cooled the Ordovician: Nature Geoscience, 5, 86-89.

Lupachev, A.V., Abakumov, E.V., 2013, Soils of Marie Byrd Land, West Antarctica: Eurasian Soil Science, 46, 10(10), 994-1006.

Makeev, V.M., 1972, The new data on the relief of the Schirmacher Oasis and the history of its development: Proceedings of the Soviet Antarctic expedition, 60, 48-64.

Matsuoka, N., 1995, Rock weathering processes and landform development in the Sør Rondane Mountains, Antarctica: Geomorphology, 12(4), 323-339.

McCarroll, D., Viles, H., 1995, Rock-weathering by the lichen Lecidea auriculata in an arctic alpine environment: Earth Surface Processes and Landforms, 20(3), 199-206. 
Mergelov, N.S., 2014, Soils of the wet valleys in Larsemann Hills and Vestfold Hills oases (Princess Elizabeth Land, East Antarctica): Eurasian Soil Science, 47(9), 845-862.

Mergelov, N.S., Goryachkin, S.V., Shorkunov, I.G., Zazovskaya, E.P., Cherkinsky, A.E., 2012, Endolitic pedogenesis and rock varnish on massive crystalline rocks in East Antarctica: Eurasian Soil Science, 45(10), 901-917.

Michel, R.F.M., Schaefer, G.E.G.R., Dias, L.E., Simas, F.N.B., de Melo-Benites, V., de SáMendonça, E., 2006, Ornithogenic Gelisols (Cryosols) from maritime Antarctica: Soil Science Society of America Journal, 70(4), 1370-1376.

Nesbitt, H.W., Young, G.M., 1996, Petrogenesis of sediments in the absence of chemical weathering: effects of abrasion and sorting on bulk composition and mineralogy: Sedimentology, 43(2), 341-358.

Olech, M., Singh, S.M., 2010, Lichens and lichenicolous fungi of Schirmacher Oasis, Antarctica: India, Goa, National Center of Antarctic and Ocean Research, Ministry of Earth Sciences, Government of India, 140 p. Pagliai, M., Stoops, G., 2010, Physical and biological surface crusts and seals, in Stoops, G., Marcelino, V., Mees, F. (eds), Interpretation of micromorphological features of soils and regoliths: Amsterdam, The Netherlands, Elsevier, 419-440.

Pichler, H., Schmitt-Riegraf, C., 1997, Rockforming Minerals in Thin Section: Amsterdam, The Netherlands, Springer, 221 p.

Quirk J., Beerling, D.J., Banwart, S.A., Kakonyi, G., Romero-Gonzalez, M.E., Leake, J.R., 2012, Evolution of trees and mycorrhizal fungi intensifies silicate mineral weathering: Biology Letters, 8(6), 1006-1011.
Ríos De los, A. L., Wierzchos, J., Sancho, L. G., Ascaso, G., 2003, Acid microenvironments in microbial biofilms of Antarctic endolithic microecosystems: Environmental microbiology, 5, 4, 231-237.

Robinson, R.S., Johnsson, M.J., 1997, Chemical and physical weathering of fluvial sands in an Arctic environment; sands of the Sagavanirktok River, North Slope, Alaska: Journal of Sedimentary Research, 67(3), 560-570

Rogov, V.V., 2000, Characteristic features of particle morphology in the skeleton of cryogenic eluvium: Earth's Cryosphere, 4(3), $67-74$.

Scarciglia, F., Saporito, N., La Russa, M.F., Le Pera, E., Macchione, M., Puntillo, D., Crisci, G.M., Pezzino, A., 2012, Role of lichens in weathering of granodiorite in the Sila uplands (Calabria, southern Italy): Sedimentary Geology, 280, 119-134.

Sedov, S.N., Shoba, S.A., 1996, Methods of investigating a mineral skeleton of soils: Assessment of possibilities and application to solving soil-genetic problems: Eurasian Soil Science, 29(10), 1081-1089.

Shmelev, D.G., 2015, Role of cryogenesis in the formation of composition of the late Quaternary deposits in Antarctic oases and North-East Yakutia: Earth's Cryosphere, 19(1), 41-57 [in Russian].

Simas, F.N.B., Schaefer, G.E.G.R., Filho, M.R.A., Francelino, M.R., Filho, E.I.F., da Costa, L.M., 2008, Genesis, properties and classification of Cryosols from Admiralty Bay, maritime Antarctica: Geoderma, 144(12), 116-122.

Simonov, I.M., 1971, Oasis of Eastern Antarctica: Leningrad, USSR, Gidrometeoizdat, 181 p. [in Russian]. 
Souza-Egipsy, V., Wierzchos, J., Sancho, C., Belmonte, A., Ascaso, C., 2004, Role of biological soil crust cover in bioweathering and protection of sandstones in a semiarid landscape (Torrollones de Gabarda, Huesca, Spain): Earth Surface Processes and Landforms, 29(13), 1651-1661.

Srivastava, A.K., Ingle, P.S., Khare, N., 2010, Textural characteristics, distribution pattern and provenance of heavy minerals in glacial sediments of Schirmacher Oasis, East Antarctica: Journal of Geological Society of India, 75(2), 393-402.

Srivastava, A.K., Khare, N., Ingle, P.S., 2011, Characterization of clay minerals in the sediments of Schirmacher Oasis, East Antarctica: their origin and climatological implications: Current Science, 100(3), 363-372.

Srivastava, A.K., Ingle, P.S., Lunge, H.S., Khare, N., 2012, Grain-size characteristics of deposits derived from different glacigenic environments of the Schirmacher Oasis, East Antarctica: Geologos, 18(4), 251-266.

Stoops, G., 2003, Guidelines for analysis and description of soil and regolith thin sections: Madison, U.S.A., Soil Science Society of America, $184 \mathrm{p}$.

Svirčev, Z., Marković, S.B., Stevens, T., Codd, G.A., Smalley, I., Simeunović, J., Obreht, I., Dulić, T., Pantelić, D., Hambach, U., 2013, Importance of biological loess crusts for loess formation in semi-arid environments: Quaternary International, 296, 206-215.

Targulian V., Mergelov , D. Gilichinsky, S. Sedov, N. Demidov, Goryachkin S., Ivanov A., 2010, Dokuchaev's Soil Paradigm and Extraterrestrial Soils, in Gilkes, R.J., Prakongkep, N. (eds.), Proceedings of the 19th World Congress of Soil Sciences, Soil Solutions for a Changing World: Brisbane, Australia, IUSS, 1-4.

Tedrow, J.G.F. , 1991, Pedologic linkage between the cold desert of Antarctica and the polar deserts of the high Arctic, in Elliot, D.H.,
Contributions of Antarctic Research II: Washington, D.C., U.S.A., American Geophysical Union, Antarctic Research Series, 53, 1-17.

Tedrow, J.G.F., Ugolini, F.C., 1966, Antarctic soils, in Tedrow, J.C.F. (ed.), Antarctic Soils and Soil Forming Processes: Washington, D.C., U.S.A., American Geophysical Union, Antarctic Research Series, 8, 161-177.

Ugolini, F.G., Jackson,M.L., 1982, Weathering and mineral synthesis in Antarctic soils, in Craddock, C. (ed.), Antarctic Geoscience: Madison, U.S.A., University of Wisconsin Press, 1101-1108.

Verkulich, S.R., Pushina, Z.V., Sokratova, I.N., Tatur, A., 2011, Change of glaciation in Schirmacher Oasis (East Antarctica) from the end of the Late Pleistocene: Ice and Snow, 2(114), 116-122 [in Russian].

Vlasov, D.Yu., Abakumov, E.V., Nadporozhskaya, M.A., Kovsh, N.V., Krylenkov, V.A., Lukin, V.V., Safronova, E.V., 2005, Lithosols of King George Island, western Antarctica: Eurasian Soil Science, 38(7), 681-687.

Wentworth, S.J., Gibson, E.K., Velbel, M.A., McKay, D.S., 2005, Antarctic Dry Valleys and indigenous weathering in Mars meteorites: Implications for water and life on Mars: Icarus, 174(2), 383-395.

Zazovskaya, E.P., Fedorov-Davydov, D.G., Alekseeva, T.V., Dergacheva, M.I., 2015, Soils of Queen Maud Land, in Bockheim, J.G. (ed.), The Soils of Antarctica: New York, U.S.A., Springer International Publishing, 21-44.

Zazovskaya, E., Mergelov, N., Shishkov, V., Dolgikh, A., Miamin, V., Cherkinskiy, A., Goryachkin, S., 2017, Radiocarbon age of soils in Oases of East Antarctica: Radiocarbon, 59(2), 489-503.

Zech, R., 2012, A permafrost glacial hypothesis - Permafrost carbon might help explaining the Pleistocene ice ages: E\&G Quaternary Science Journal, 61(1), 84-92. 